\title{
Impact of Corporate Social Responsibility on Financial Performance Evidence from Pharmaceutical Sector Listed Companies of Pakistan
}

\author{
Irfan Rana*, Faizan Asad \\ School of Accounting \& Finance, University of Central Punjab, Lahore, Pakistan \\ Email address: \\ irana@wwf.org.pk (I. Rana) \\ ${ }^{*}$ Corresponding author
}

To cite this article:

Irfan Rana, Faizan Asad. Impact of Corporate Social Responsibility on Financial Performance Evidence from Pharmaceutical Sector Listed Companies of Pakistan. European Business \& Management. Vol. 4, No. 1, 2018, pp. 1-8. doi: 10.11648/j.ebm.20180401.11

Received: September 24, 2017; Accepted: October 26, 2017; Published: December 5, 2017

\begin{abstract}
The purpose of this study was to examine the impact of Corporate Social Responsibility (CSR) on Financial Performance (FP) of pharmaceutical sector companies listed in Pakistan Stock Exchange (PSX). According to published data of Pakistan Stock Exchange (PSX), a total of 9 pharmaceutical companies are reported in this sector. In order to achieve the purpose, data has been collected of three years from 2014 to 2016 from annual reports of the companies. In this study the spending on Education, Healthcare and Environment, Donation, and Workers Welfare Fund used as proxy for CSR measurement, while three proxies of Donation, Earning per Share (EPS), Return on Assets (ROA), and Return on Equity (ROE) as measurement of financial performance. Data has been analyzed using Panel Least Square Fixed Effect Regression. The findings $s$ of the study revealed that there is positive impact of CSR on Financial Performance of the companies. It is evident that to boost the financial performance, the CSR phenomenon is an essential tool for growth in pharmaceutical industry of Pakistan.
\end{abstract}

Keywords: Financial Performance, Corporate Social Responsibility, Pharmaceutical Sector, Fixed Effect Panel Regression

\section{Introduction}

Corporate Social Responsibility (CSR) is the relationship of a company with society all in all. It has been defined by various specialists in various styles. McWilliams and Siegel (2001) [14] portray CSR as "Doing every one of those activities which are not constrained by law of those nations in which they are maintaining their business and which are not for the essential advantages of the business but rather for the advantages of the general public."

For verifying any concept, there should be a theory base. Hajji and Ghazali (2012) [24] considered the company social obligation with the point of view of legitimacy theory in Malaysia. They contemplated eighty five companies of Malaysia that were recorded amid situation of financial crisis. As a rule, theory gives chance to the general public and examines the demand which stakeholders (society) has from company. Stakeholder theory examines various stakeholders of company on how a company treats their stakeholders. This theory utilizes to think about the effect of corporate social obligation divulgence on financial execution

CSR can have a genuine effect to financial improvement situation in creating and immature countries. In Corporate Social Responsibility, organizations at the same time deal with hierarchical objectives and societal interests by being in charge of the effect of their exercises on different partners. CSR is increasing much prominence and essentialness around the world, obliging an assortment of social and monetary issues which moderate countries are defying with. It is the commitment of company to give their rights and treats reasonably. Various organizations issue disclosures about the CSR these days. The request of individuals who influence the company (stakeholders) is persistently scaling up for enterprises to gauge reports and boost their social, environmental, and economic execution

In Pakistan, the part of corporate segment has been much conventional and remained prisoner to financial contemplations, setting group intrigues aside for later. CSR 
has been the most disregarded issue in Pakistan in view of disparity of interests between corporate part and society. Social part has been the most dismissed segment in Pakistan. Interest in training and wellbeing has been minimal since the start. The horrid picture financial needs and accomplishments leaves the nation powerless against financial advancement development (both social and monetary) combined with rare assets unequivocally recommend the characterized corporate segment a save to the country's circumstance and compensate for the cut in government spending on wellbeing and training.

SECP issued in 2009 the general order pertaining to corporate social responsibility for all companies. As per order, for each company it is obligatory to give disclosure in descriptive form as well figures related to CSR initiatives that were undertaken during the year. This disclosure is part of report from directors to the shareholders that is part of the annual audited accounts. However, the companies had liberty to decide the format and content of CSR report. The essence was to create a strong perception as reports are channel of public relation rather than accountability causing. For reason of inconsistency in reporting format, the stakeholders became unclear and to assess the true status of company regarding CSR priority activities, evaluate the utilization of resources and the impact there of. SECP, in 2012, issued guidelines of CSR activities reporting. These guidelines are a major step towards standardizing the reporting requirements, and making accountable the CSR activities by listed companies.

To probe and analyze the relationship of CSR and FP, the pharmaceutical sector companies of Pakistan listed in PSX have been selected for this study. Reason behind is the curiosity that no pharmaceutical company has been highlighted in reports of Pakistan Centre of Philanthropy (PCP) which have been tracking the progress made by the corporate sector over a decade. According to the latest report of PCP in 2014 the top 25 companies contributed more than $54 \%$ of the total donations in 2014 , and surprisingly there is no pharmaceutical company in the list, while this sector is a key sector among those contributing significant amount to GDP. Pharmaceutical sector contributes \$1.6 Billion towards Gross Domestic Product (GDP).

Pakistan is the $8^{\text {th }}$ largest pharmaceutical manufacturing industry; it creates significant revenue for the government in form of taxes, and also provides employment opportunities for a large number of people. Success of this sector is ultimately contributed to the financial development. In this study, it will be investigated that how much amount is being spent on donation and CSR activities and thereon what is impact on financial performance of companies.

\section{Literature Review}

From the most investigations by Bowen (1953), Eells and Walton (1961) [1], Carroll (1979) [2], McGuire (1963) [3] the significance of CSR and it impact on society has been investigated from different perspectives. Be that as it may, their suppositions are separated on the requirement for corporate CSR. A few examinations with a positive evaluation of CSR contended that 'a company has an obligation to society' (Carroll 1979 [2]; Drucker 1984 [4]; Davis and Blomstrom 1975 [5], Andrews 1973 [6], Epstein 1987) [7], while others announced that 'an organization justhas the obligation to augment its advantage inside the fence of law and least moral confinements' (Friedman 1970) [9].

Up until this point, the position of corporate social responsibility is at its untimely level in creating nations (Mujahid and Abdullah, 2014) [10]. Because of fast communication, thought of globalization and industrialization age significant enthusiasm for the most recent few years, in the CSR has encountered. On this start, the business challenges have expanded everywhere; new requests for enhanced straightforwardness alongside improved corporate behavior are requested (Jamali and Irfan, 2007) [11]. Malik ji and Nadeem (2014) [12] expressed that CSR has ended up being the very much perceived and interesting issue over the most recent few years. They additionally contended that in nowadays, the majority of the organizations in the business world issue CSR reports alongside their abrogate proclamations.

The society that impact the organizations undertakings requested to have a more enhance social, financial and the natural advantages. All the more critically, modernization, mechanical information, commercialization, monetary coordination, unpredictable financial circumstances and globalization have created pressure on the company. By viewing this reality, creating countries need a few components for survival particularly when they are working together around the world. The thought of CSR and FP are basic for the company long run achievement and its positive attitude. On these principles, there involves consideration and there is information crevice so it is trusted that there is a desire to contemplate effect of CRS on company's FP of chosen banks recorded in PSX.

M. Shoukat Malik Ji, Muhammad Nadeem (2014) [31] under the title "Effect of corporate social obligation on the money related execution of banks in Pakistan" concluded that banks should satisfy their social duties that will enhance image in the general public. Economic and ecological conditions of Pakistan prompt good picture of banks, and every other stakeholders with respect to the organizations.

Samrana Kiran, Shahid Jan Kakakhel and Fauzia Shaheen (2015) [25] led ponder under title "Corporate Social Responsibility and firm Profitability of Oil and Gas Sector of Pakistan", and dissected that positive relationship exists amongst CSR and net benefit and net revenue, while there is negative connection between add up to resources and CSR. Relapse result proposes a unimportant effect of CSR exercises on benefit.

As indicated by Jie, C. T., Hasan, N. A. M. (2016) [26] "Effect of Corporate Social Responsibility Disclosure on Financial Performance: Case Study of Listed Pharmaceutical Firms of Pakistan" a strong relationship exists between CSR and growth of sales. 
The CSR is one of the challenging issues of the modern corporate community as well as in the area of leadership in view of broad spectrum. It has brought attention, gained recognition and got a vital importance across the globe. In the tough competitive environment of modern business, the sustainability of the business mostly relies on the effectiveness and efficiency of the financial management function. It has become a test for CEOs, and they are required to pay attention and ultimately to be questioned (Akinyomi, 2013) [13]. As per McWilliams and Siegel (2001) [14] CSR is meant to perform all those activities that are not compulsory by regulations of those countries rather these are for benefits of the society Similarly, businesses are persistent to CSR practices irrespective of nature of business activities, and they fulfill commitment by complying to ethics and improving the living standard of people and contributing to economic development as well. They also said that the CSR is assumed the part of corporate governance in contemporary best practices, currently, is coming under the good governance (Mughal, 2014) [15].

In the present world, most of the companies that are centric to profit making are confined. Companies will no longer sustain that are silent to the needs of society. These days' societies are expecting from companies to be and act like a good corporate citizen and contribute for the development and betterment. (Belal and Momin, 2009) [16]. According to Wibisono (2007) [17], the practicing of CSR, is taken as an investment rather than an expense. Today, companies understood the value of CSR and its long term impact, so these are allocating more resources and being aligned with strategically to harness the balance in economic and social aspects.. Besides this, companies are strivingto recognize this phenomenon and creating social value along with wealth increasing through profit (Yang et al., 2010 [18]; KPMG, 2011) [19]. Irrespective of all. The activities linked with CSR are surely be resulting into societal betterment (Nelling and Webb, 2009) [20]. Customers are more informative and sensitive, and demand ethical behavior alongside good quality and low price product. Governments are tightening the rules and regulations for the companies to ensure they comply with the need of ethical behaviors and raising up themselves to assimilate CSR as part of their business strategy that embraces socio and environmental focuses. (Kashyap et al., 2006) [21]. Most of the MNCs have understood the importance and benefit of implementing corporate social responsibility and consequently their financial performance is increasing sharply. (Poddi et al., 2009) [22]. Recently, in a few years' time, the concept of CSR has gained much popularity and significance worldwide as catering to a variety of social and economic problems which conservative nations are confronting with, is the one among the top priorities of this century.. It is obligatory to the organization to give their rights and treats fairly. Last couple of years the socio economic issues faced by countries and organizations have instigated the scholars to investigate the role of CSR in organization sustainable performance and what sort of relationship exists between organization behavior and CSR. (Burton and Goldsby, 2009) [23].

\section{Problem Statement}

Factors of globalization and intense competition in the business market of world have pushed the business leaders and developed countries to embrace the CSR, and they are now more into it to investigate the linkages and returns. The subject of CSR has not yet been understood and explored in the developing countries like Pakistan. It is far behind in comparison to others. The social and economic indicators of Pakistan continue to be ranked very low in the comity of the nation even when compared to other developing and emerging economies.

So far a number of researches have been done to determine the relation between CSR on financial performance, and general finding or conclusion drawn (with some exceptions) is the presence of positive relationship between CSR and financial performance. It reckons that CSR implementation and disclosure influences the relationship with outside stakeholders, accordingly.

Pakistan, a developing country, being stuck among various issues and challenges of terrorism, inflation, lack of health, natural disasters, and industrial crises, and educational infrastructure and political, economic instability is still reluctant to spend on CSR activities, and, specially, of nonservice sector. Reasons behind is the fact that it is involved in the production of products, deals with machinery and different types of risky materials which require more sensitive health and safety precautions for working force at plant and surrounding community, therefore it requires awareness and being more conscious about CSR, and demands a handsome amount of effort and expenses. Because of this myth, most of the organizations in Pakistan are not tilted towards CSR activities because they presume it as a cut to companies' profits as it does not correspond with the economic role of the firm. Here a question comes into mind whether is it true that volume of CSR efforts lowers the impact, and companies are more inclined to hold spending on CSR.

Although, several studies have been executed in Pakistan on examining the association between CSR and FP in different sectors, but the Pharmaceutical sector has not yet been studied. Also, Pakistan Centre of Philanthropy (PCP) that tracks the philanthropy tendency of corporate sector on regular basis has not yet identified any pharmaceutical company. A knowledge gap is exiting in form of not analyzing the CSR spending of Pharmaceutical companies, and investigating the impact on financial performance.

\section{Research Objectives}

To investigate the effect of corporate social responsibility on financial performance of Pharmaceutical companies listed in PSX. 


\section{Significance of the Study}

This probing will investigate if the relation between CSRand FP in Pharmaceutical companies exists or not, and what is the significance of relationship. Results of the study will be of high interest to pharmaceutical companies and also to other sectors companies, decision makers, policy makers, Pakistan Centre of Philanthropy and security Exchange Commission (SECP). Further, the study results and recommendations will carry high value and substance to the researchers who are investing the relationship from different aspects. If results reject the hypothesis of positive relationship then it will trigger the new dimension of research area.

The study will bring new avenue of knowledge about social activism undertaken by pharmaceutical industry and thereby the performance behavior. Study will also assist policy makers in developing strategies by assimilatingsocio and economic aspects, consequently sustainable growth will be seen, specifically for pharmaceutical companies under this study by proving the impact of CSR on the FP.

\section{Theoretical Frame Work}

Literature review has revealed that excellent work has already been done on linkages between CSR and organization performance, but these studies have conducted in the developed countries.. Whereas, there is limited amount of proof from developing countries nations like Pakistan. Further, to this gap in knowledge, the present literature is not adequate and lacks harmony, agreement and analogy, and it needs verification from less developed countries. Therefore, the purpose and zeal behind the study is to add value in the literature with further study and making up the knowledge gap flagged in the literature concerning CSR and FP and to offer worthy suggestions to pharmaceutical sectorleaders and policy makers (Figure 1).

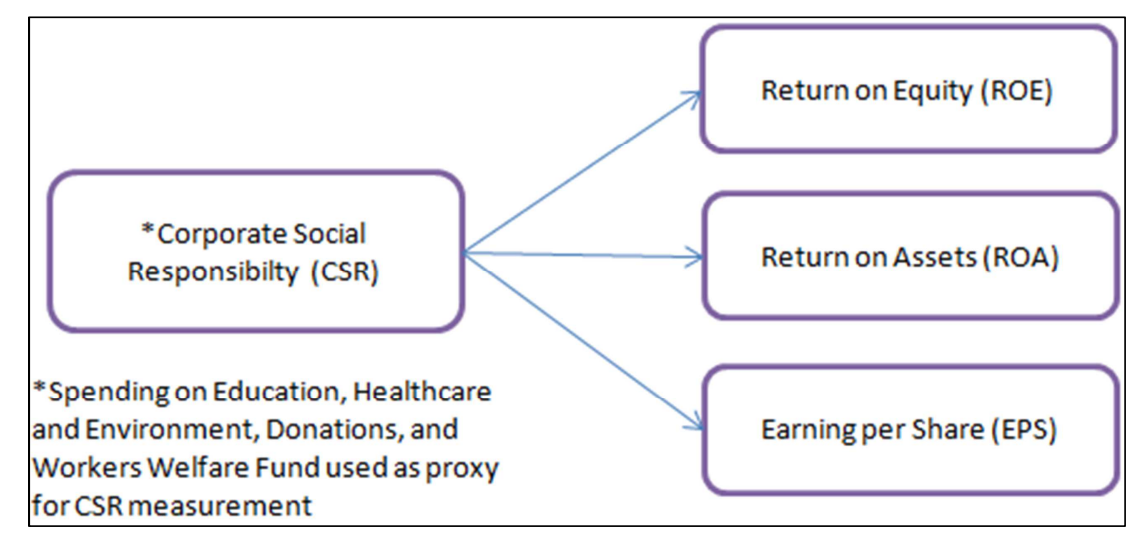

Figure 1. Impact of ROE, ROA and EPS on CSR.

\section{Methodology}

\subsection{Research Model}

As indicated by the kind of study and research objective, the below given model of econometrics is applied to exam the hypothesis:

$$
\mathrm{FP}=\beta_{0}+\beta_{1} \mathrm{CSR}+\varepsilon
$$

To practicalizethe research objective above regression equation is divided into three equation one-to-one to each proxy of Financial Performance.

$$
\begin{aligned}
& \mathrm{ROA}=\beta_{0}+\beta_{1} \mathrm{CSR}+\varepsilon \\
& \mathrm{ROE}=\beta_{0}+\beta_{1} \mathrm{CSR}+\varepsilon \\
& \mathrm{EPS}=\beta_{0}+\beta_{1} \mathrm{CSR}+\varepsilon
\end{aligned}
$$

Where,

FP signifies financial performance, ROA denotes return on assets, ROE defines return on equity and EPS signify earnings per share which has been taken as proxies of DV means dependent variable whereas CSR denotes corporate social responsibility CSR treated as IV means independent variable and $\varepsilon$ is helping as an error term in the equation of the study.

\subsection{Variables Description}

\subsubsection{CSR}

The spending on Education, Healthcare and Environment, Donation, and Workers Welfare Fund used as proxy for CSR measurement extracted from CSR reports of pharmaceutical Companies under study.

\subsubsection{FP}

Financial Performance is dependent variable which is measured by using generally suitable for accounting measures ROA, ROE and EPS respectively. Financial reports represent FP status and strength of an organization at a specific point of time, and in a financial year. However, choice of using ROE, ROA and EPS as sound proxies. Study variables and consequent measures were presented in the Appendix I.

\subsubsection{Population and Sampling}

All pharmaceutical Companies listed in the PXS have been chosen for the purpose of investigation and data collection which shown in (Appendix II). 


\subsubsection{Data Source and Statistics}

This study constructed on base of secondary data.

\section{Result and Discussion}

Table 1 shows the statistical harvest of Equation (i) for the impact of CSR on ROA. P value of corresponding to CSR is satisfying the significance criteria, and so the first hypothesis (H1) is accepted which indicates that CSR has significant and positive impact of CSR on the ROA of selected pharmaceutical Companies of Pakistan (H1). And the Adjusted $\mathrm{R}^{2}$ (coefficient of the determination) value is $82.36 \%$ defines the deviation or variability in the dependent variable. ROA is explained by explanatory variable and CSR of the selected pharmaceutical Companies of Pakistan which also catching the maximum variation of the model.

Table 1. The CSR and ROA.

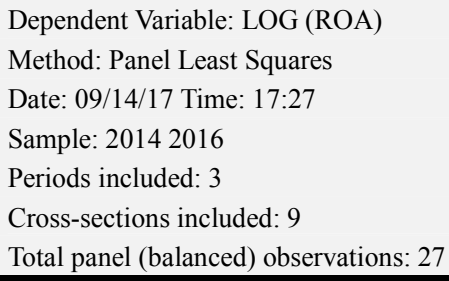

Dependent Variable: LOG (ROA)

Method: Panel Least Squares

Date: 09/14/17 Time: 17:27

Sample: 20142016

Periods included: 3

Cross-sections included: 9

Total panel (balanced) observations: 27

\begin{tabular}{lllll}
\hline Variable & Coefficient & Std. Error & t-Statistic & Prob. \\
\hline C & -4.649443 & 2.054922 & -2.262589 & 0.0370 \\
LOG(CSR) & 0.760119 & 0.218878 & 3.472794 & 0.0029 \\
\hline
\end{tabular}

\begin{tabular}{llll}
\hline \multicolumn{4}{c}{ Effects Specification } \\
\hline Cross-section fixed (dummy variables) & \\
\hline R-squared & 0.823693 & Mean dependent var & 2.480652 \\
Adjusted R-squared & 0.730354 & S. D. dependent var & 0.858656 \\
S. E. of regression & 0.445878 & Akaike info criterion & 1.500574 \\
Sum squared resid & 3.379719 & Schwarz criterion & 1.980513 \\
Log likelihood & -10.25774 & Hannan-Quinn criter. & 1.643285 \\
F-statistic & 8.824766 & Durbin-Watson stat & 3.135358 \\
Prob (F-statistic) & 0.000074 & & \\
\hline
\end{tabular}

The remaining $(17.64 \%)$ is the error term in model indicates unexplained fraction, $\mathrm{F}$ value is used to check the overall fitness of the model. It is shrewd from the significance column the $\mathrm{F}$ statistics and $\mathrm{P}$ value which is less than the 0.05 which is the standard. It is suggesting that the first regression model has the prognostic power and potency to significantly forecast the outcome of variable. In the Table 1 the value of $\beta$ value is in positive direction and P-value is lesser than the 0.05 which is the standard so it determines that there is a positive and statistically significant impact of CSR on ROA of selected Pharmaceutical Companies of Pakistan. On this result the first hypothesis is accepted. The results are in line with (Choi et al., 2010 [29]; Iqbal et al., 2013 [30]; Ofori et al. 2014 [32]; Kiran et al., 2015 [27]; Murtaza et al., 2014) [28]. Moreover, the first model DurbinWatson stat value 3.135358 which signifies that the model one is free from multicollinearity.
Table 2. The corporate social responsibility and $R O E$.

\begin{tabular}{|c|c|c|c|c|}
\hline \multicolumn{5}{|c|}{ Dependent Variable: LOG (ROE) } \\
\hline \multicolumn{5}{|c|}{ Method: Panel Least Squares } \\
\hline \multicolumn{5}{|c|}{ Date: 09/14/17 Time: 17:24 } \\
\hline \multicolumn{5}{|c|}{ Sample: 20142016} \\
\hline \multicolumn{5}{|l|}{ Periods included: 3} \\
\hline \multicolumn{5}{|c|}{ Cross-sections included: 9} \\
\hline \multicolumn{5}{|c|}{ Total panel (balanced) observations: 27} \\
\hline Variable & Coefficient & Std. Error & t-Statistic & Prob. \\
\hline $\mathrm{C}$ & -2.577750 & 2.367357 & -1.088873 & 0.2914 \\
\hline LOG (CSR) & 0.612021 & 0.252157 & 2.427145 & 0.0266 \\
\hline \multicolumn{5}{|c|}{ Effects Specification } \\
\hline \multicolumn{5}{|c|}{ Cross-section fixed (dummy variables) } \\
\hline R-squared & 0.818286 & Mean depe & dent var & 3.163157 \\
\hline Adjusted R-squared & 0.722084 & S. D. deper & ent var & 0.974378 \\
\hline S. E. of regression & 0.513670 & Akaike inf & criterion & 1.783646 \\
\hline Sum squared resid & 4.485568 & Schwarz cr & erion & 2.263586 \\
\hline Log likelihood & -14.07922 & Hannan-Q & an criter. & 1.926357 \\
\hline F-statistic & 8.505941 & Durbin-Wa & on stat & 2.590557 \\
\hline Prob (F-statistic) & 0.000094 & & & \\
\hline
\end{tabular}

Statistical output of the regression analysis of Equation (ii), is presented in the Table 2 and similar to Equation (i), hypothesis (H2) is accepted because the $\mathrm{P}$ is less than 0.05 which indicates the significant impact of CSR on ROE of selected pharmaceutical Companies of Pakistan. And the Adjusted $\mathrm{R}^{2}$ (coefficient of the determination) $81.82 \% \%$ defines the deviation or variability in the dependent variable in the ROE is observed by CSR and the remaining different i. e. $18.18 \%$ could be clarified as unexplained aspect with error term. In addition, it is keen from the significance column the F statistics and P is 0.000094 which is less than the standard.

It is statistically significant, second model similarly first model is vigorous to predict the effect of the variable. The value of $\beta$ is positive and $P$ value which is lesser than the 0.05 which proves that there is a positive and statistically significant impact of the CSR on ROE of selected pharmaceutical Companies of Pakistan. On this ground the second hypothesis (H2) is accepted. The results are in confirmation with previous studies with (Choi et al., 2010 [29]; Iqbal et al., 2013 [30]; Ofori et al. 2014 [32]; Kiran et al., 2015 [27]; Murtaza et al., 2014) [28]

Table 3. The CSR and EPS.

Dependent Variable: LOG (EPS)

Method: Panel Least Squares

Date: 09/14/17 Time: 17:23

Sample: 20142016

Periods included: 3

Cross-sections included: 9

Total panel (balanced) observations: 27

\begin{tabular}{lllll}
\hline Variable & Coefficient & Std. Error & t-Statistic & Prob. \\
\hline C & -5.551953 & 2.059925 & -2.695221 & 0.0153 \\
LOG (CSR) & 0.896945 & 0.219411 & 4.087963 & 0.0008 \\
\hline
\end{tabular}




\begin{tabular}{llll}
\hline \multicolumn{4}{c}{ Effects Specification } \\
\hline Cross-section fixed (dummy variables) & \\
\hline R-squared & 0.838236 & Mean dependent var & 2.861601 \\
Adjusted R-squared & 0.752596 & S. D. dependent var & 0.898605 \\
S. E. of regression & 0.446963 & Akaike info criterion & 1.505438 \\
Sum squared resid & 3.396198 & Schwarz criterion & 1.985377 \\
Log likelihood & -10.32341 & Hannan-Quinn criter. & 1.648149 \\
F-statistic & 9.787930 & Durbin-Watson stat & 3.177871 \\
Prob (F-statistic) & 0.000038 & & \\
\hline
\end{tabular}

Table 3 states the regression equation (iii) output for CSR on EPS while $\mathrm{P}$ value and coefficient indicate the positive significant impact of CSR on EPS, thus hypothesis (H3) is accepted. And Adjusted $\mathrm{R}^{2}$ (coefficient of the determination) $83.82 \%$ defines the variability in the dependent variable which EPS can be explained by explanatory variable CSR of selected pharmaceutical Companies of Pakistan. The remaining $16.18 \%$ is not clarified by model, which may due to unknown factors which is known as error term.

In addition, it is intuitive from $\mathrm{F}$ statistics and $\mathrm{P}$ value (0.000038), which is below than 0.05 . The value of $F$ test telling that has the prominent control to significantly forecast the effect of the variable. The value of $\beta$ is positive and $P$ value is less than 0.05 which is confirming that there is a positive and statistically significant impact of the CSR on EPS of selected pharmaceutical Companies of Pakistan. On this evidence the third hypothesis (H3) is accepted. The results are also in conformism with previous studies with (Choi et al., 2010 [29]; Iqbal et al., 2013 [30]; Ofori et al. 2014 [32]; Kiran et al., 2015 [27]; Murtaza et al., 2014) [28]

It is evident from the empirical results that when the Pakistani pharmaceutical companies increase the spending in CSR activates; in turn the Financial Performance of pharmaceutical Companies under study will also increase.

\section{Conclusion and Recommendation}

Intensity of money related part has expanded complex and the issue of CSR has turned into an imperative concern parallel to the focusing on benefit. The organizations are viewed as social elements; they need to serve partners, and have a tendency to execute CSR on need premise and resulting revelation also. The fundamental reason for introduce consider is to reveal insight into the effect of CSR on FP of pharmaceutical Companies of Pakistan, utilizing a specimen pharmaceutical Companies recorded on PSX for the time of 3 years from 2014 to 2016, chose on the premise of market capitalization. We connected Panel relapse models to explore the effect of CSR on generally utilized intermediaries of FP; ROE; ROA and EPS, have been utilized to gage FP. Observational discoveries connote the power of pooled demonstrate that reported a positive and noteworthy effect of CSR on ROE, ROA and EPS, this introduce holds that CSR has positive and critical effect on FP of chose pharmaceutical Companies of Pakistan. In view of key discoveries, this investigation hypothesizes CSR marvel is considered as a basic development component and FP boosting apparatus and pharmaceutical Companies of Pakistan. In the long run, standard of the examinations on CSR is in setting of settled organizations yet less are in setting of creating country and this investigation contributes by approving key discoveries of past examinations, along these lines the finding of this investigation are thusly of more noteworthy significance for strategy producers and supervisors.

Following imperative approach suggestions are given in view of the discoveries of the examination:

i. CSR has turned into an all-inclusive wonder with rising worthiness among all partners. Especially units are presently viewed as social units; they need to serve partners, and have a tendency to perform CSR on need premise and ensuing revelation too. As indicated by McWilliams and Siegel (2001) CSR rehearses are not constrained by law, yet deliver hopeful yield and positive effect on gainfulness, should be incorporated among key business strategies for long run achievement.

ii. Unplanned and bad CSR arrangements may cause damage to partners' interests and benefits, and frustrated partners may pivot as surrendered client and in addition wellspring of declining profit.

iii. Furthermore, arrangement producers are proposed to ensure CSR related revelation, that won't just yield productivity yet in addition it will amplify the market estimation of offers of that unit, eventually gathering of complex social and financial advantages.

iv. In expansion, in view of key discoveries, this examination hypothesizes that CSR marvel as a basic development component and FP-boosting tool.

In the end, standard of the examinations on CSR are in setting of settled organizations and countries, in any case, creating countries are slightest stressed, along these lines the discoveries of this investigation incredibly contribute in collection of information and also offer crucial ramifications for arrangement creators and administration of money related part.

The discoveries of the investigation are unequipped for speculation because of the accompanying constraints: Firstly, the examination has considered just pharmaceutical Companies, albeit number of firms are recorded with PSX, accordingly, the model can be utilized with generally huge specimen estimate from Pakistan.

Also, it utilized 3 years information for investigation, by and by we discovered positive huge effect of CSR on FP, yet expanded time traverse thought may deliver fascinating outcomes.

Thirdly, there is modest bunch writing accessible on CSR in less created or creating nations and we accounted just Pakistan, in spite of the fact that an arrangement of five or more noteworthy specimen of creating nations for investigation would think of generally strong conclusion.

Fourthly, it is balanced to think about the arrangement of creating and created country to examine the CSR hones and resulting sway on FP.

Finally, it is suggested that anticipating shareholder wealth maximization is comparatively more solid and realistic measure of financial performance (as dependent variable) rather than traditional proxies of FP (ROE, ROA and EPS). 
Appendix I: The Study Variables and Measurement

\begin{tabular}{ll|l}
\hline Description & Symbols & How to measure \\
\hline $\begin{array}{l}\text { DV } \\
\begin{array}{l}\text { Proxies to FP } \\
\text { Return on assets }\end{array}\end{array}$ & \\
$\begin{array}{l}\text { Return on equity } \\
\text { Earnings per shares }\end{array}$ & ROA & ROA=Net profit /total assets \\
IV & ROE & ROE=Net profit /shareholders' equity \\
$\begin{array}{l}\text { Proxies to CSR } \\
\text { Education }\end{array}$ & EPS & \\
$\begin{array}{l}\text { Healthcare and Environment } \\
\text { General donation }\end{array}$ & CSR & Annual Contribution to Education \\
Donation to society & CSR & Annual Contribution to Healthcare and Environment \\
Workers welfare fund & CSR & Annual Contribution to General donation \\
\hline
\end{tabular}

CSR: Corporate social responsibility, ROA: Return on assets, ROE: Return on equity, EPS: Earnings per share, FP: Financial performance.

\section{Appendix II: List of Pharmaceutical Companies Analyzed (Listed with PSX)}

\begin{tabular}{ll}
\hline Serial No. & Name of Companies \\
\hline 1 & Abbott Lab \\
2 & Ferozsons (Lab) \\
3 & GlaxoSmithKline \\
4 & Highnoon (Lab) \\
5 & IBL HealthCareXB \\
6 & Otsuka Pak \\
7 & Sanofi-Aventis \\
8 & The Searle Co. \\
9 & Wyeth Pak Ltd \\
\hline
\end{tabular}

PSX: Pakistan stock exchange.

\section{Appendix III: Hypothesis of the Study}

\begin{tabular}{lllll}
\hline Hypothesis & & Coefficient & P value & Status \\
\hline H1 & CSR has positive and significant impact on ROA & 0.760119 & 0.0029 & Accepted \\
H2 & CSR has positive and significant impact on ROE & 0.612021 & 0.0266 \\
H3 & CSR has positive and significant impact on EPS & 0.896945 & Accepted & 0.0008 \\
\hline
\end{tabular}

Decision criteria H1 $(\mathrm{P}<0.05<0.0029)$; H2 $(\mathrm{P}<0.05<0.0266)$; H3 $(\mathrm{P}<0.05<0.0008)$. CSR: Corporate social responsibility, ROA: Return on assets, ROE: Return on equity, EPS: Earnings per share.

\section{References}

[1] Eells and Walton (1961), "Corporate social responsibility: Meeting changing expectations" (World Business Council for Sustainable Development, Geneva).

[2] Carroll, A. (1999). Corporate social responsibility-evaluation of a definitional construct. Business and Society 38, 268-295.

[3] McGuire, J., Schneeweis, T., Hill, J. (1986), an analysis of alternative measures of strategic performance. Advances in Strategic Management, 4 (2), 107-153.

[4] Drucker 1984; corporate social responsibility and its impact on financial performance: Investigation of U. S. Commercial Banks.

[5] Davis and Blomstrom 1975; Corporate social responsibility and strategic tax behavior. In: Schön, W. (Ed.), tax and corporate governance. Springer-Verlag, Berlin Heidelberg.

[6] Andrews 1973; Sustainability practices and corporate financial performance: A study based on the top global corporations. Journal of Business Ethics, 108: 61- 79.

[7] Epstein 1987). Corporate social responsibility. Ventus Publishing ApS. Cheruiyot, F., K., (2010). The relationship between corporate social responsibility and financial performance of companies listed at the Nairobi Stocks Exchange, Unpublished MBA Thesis, and University of Nairobi.

[8] Friedman, M. (1970), The Social Responsibility of Business is to Increase its Profits. New York: Times Magazine. P122-124.

[9] Mujahid, M., Abdullah, A. (2014), Impact of corporate social.

[10] Responsibility on firm's financial performance and shareholders wealth. European Journal of Business and Management, 6 (31), 181-187.

[11] Jamali, D., Mirshak, R. (2007), corporate social responsibility (CSR): Theory and practice in a developing country context. Journal of Business Ethics, 72 (3), 243-262.

[12] Malik, M. S., Nadeem, M. (2014), Impact of corporate social responsibility on the financial performance of banks in Pakistan. International Letters of Social and Humanistic Sciences, 10 (1), 9-19. 
[13] Akinyomi, O. J. (2013), Survey of corporate social responsibility practices in the Nigerian manufacturing sector. International Journal of Research Studies in Management, 2 (1), 1-10.

[14] Mcwilliams, A., Siegel, D. (2001), corporate social responsibility and financial performance: Correlation or misspecification? Strategic Management Journal, 21 (5), $603-$ 609.

[15] Mughal, S. L. (2014), corporate social disclosure: A case study.

[16] Belal, A. R., Momin, M. (2009), corporate social reporting (CSR) in emerging economies: A review and future direction. Research in Accounting in Emerging Economies, 9, 119-143.

[17] Wibisono, Y. (2007), Concept and Application of CSR. Gresik: Fascho Publishing.

[18] Yang, F., Lin, C., Chang, Y. (2010), the linkage between corporate social performance and corporate financial performance. African Journal of Business Management, (4) 4, 406-413.

[19] KPMG. (2011), KPMG International Survey of Corporate Responsibility Reporting. 2011. Available from: http://www.in.kpmg.com/ SecureData/aci/Files/corporateresponsibility2011.pdf. [Last accessed on 2017 Jan 02].

[20] Nelling, E., Webb, E. (2009), corporate social responsibility and financial performance: The "virtuous circle" revisited. Review of Quantitative Finance and Accounting, 32 (2), 197 209.

[21] Kashyap, R., Mir, R., Iyer, E. (2006), toward a responsive pedagogy: Linking social responsibility to firm performance issues in the classroom. Academy of Management Learning and Education, 5 (3), 366-376.

[22] Poddi, L., Vergalli, S., Mattei, F. (2009), Does corporate social responsibility affect the performance of firms. Fondazione Enri Enrico Mattei, 52 (9), 1-45.

[23] Burton, B., Goldsby, M. (2009), corporate social responsibility orientation, goals and behavior: A study of small business owners. Business and Society, 48 (1), 88-104.
[24] Haji and Ghazali (2012) the corporate social performance: Financial performance link, Strategic Management Journal, 18 (4), 303-19.

[25] Samra Kiran, Shahid Jan Kakakhel and Farzana Shaheen (2015) Managing corporate performance: Investigating the relationship between corporate social responsibility and financial performance in emerging market. International Journal of Productivity and Performance Management, 59: 229-254.

[26] Jie, C. T., Hasan, N. A. M. (2016), Determinants of corporate social responsibility (CSR) and intrinsic job motivation: A case of Malaysian banking company. Malaysian Journal of Social Sciences and Humanities, 1 (2), 25-35.

[27] Kiran, S., Kakakhel, S. J., Shaheen, F. (2015), corporate social responsibility and firm profitability: A case of oil and gas sector of Pakistan. City University Research Journal, 5 (1), 110-119.

[28] Murtaza, I. A., Akhtar, N., Ijaz, A., Sadiqa, A. (2014), Impact of corporate social responsibility on firm financial performance: A case study of Pakistan. International Review of Management and Business Research, 3 (4), 1914-1927.

[29] Choi, C. (2010), corporate social responsibility and corporate financial performance: Evidence from Korea. Australian Journal of Management, 35 (3), 291-311.

[30] Iqbal, N., Ahmad, N., Kanwal, M. (2013), Impact of corporate social responsibility on profitability of Islamic and conventional financial institutions. Applied Mathematics in Engineering, Management and Technology, 1(2), 26-37.

[31] M. Shoukat Malik, Muhammad Nadeem (2014) A threedimensional conceptual model of corporate performance; Academy of Management Review, 4 (4), 497-505.

[32] Ofori, D. F., Nyuur, R. B., S-Darko, M. D. (2014), corporate social responsibility and financial performance: Fact or fiction? A look at Ghanaian banks: Original research. Actacommercii, 14 (1), 1-11. 